up to $500 \mathrm{ft}$. height, and then succeeded in soaring up to a height of 2,150 ft. He remained in the air for 27 minutes and travelled about 10 miles altogether. Upon another occasion he ascended with a passenger, and reached a height of $1,300 \mathrm{ft}$. under very similar conditions. These are the first properly observed and recorded flights of any magnitude made in Great Britain under meteorological conditions in which there were probably no vertical air currents other than those set up by thermal convection. There were no cumulus clouds to produce the normal up currents beneath them, and there was practically no wind from which energy for soaring might have been derived. It is fair to assume that the lift necessary to raise the machine to these heights was obtained principally from currents of air rising from the heated earth. Knowing the aerodynamic characteristics of the machine, and having observed the speeds and rates of climb during such a flight, it should be possible to make fairly accurate estimations of the magnitude of these currents. Such data will have their value in meteorological statistical records.

\section{Early Culture in Northern Iraq}

Ar the close of the season's excavations at Arpachiyah, near Nineveh, the results obtained by the joint expedition of the British Museum and the British School of Archæology in Iraq had further justified the selection of this site as a possible source of information relating to the early cultural history of northern Iraq. The report on the work of the latter half of the season in the Times of July 14 opens up an enticing prospect for speculation until further discovery supplies links in the chain which now appears to connect Arpachiyah and Minoan Crete. The outstanding feature in a record of finds, which in other respects is by no means devoid of the element of surprise, is the occurrence of the double axe in the sixth level of occupation, a thousand years before it appears in Crete (where indeed Sir Arthur Evans has regarded it as intrusive from western Asia) and the discovery in the seventh level, immediately below, of beehive structures in clay and stone, similar to the beehive tombs of Crete and Mycenæan Greece. It is scarcely necessary to stress the importance of the first occurrence of such structures in Mesopotamia. These discoveries were made in excavating the summit of the mound to which operations were confined in the latter half of the season. Here no less than ten superimposed village settlements have been brought to light, all belonging to a cattle-keeping agricultural population. It is remarkable that in a community of this character the sixth settlement, nearly $20 \mathrm{ft}$. below the surface of the ground, should have yielded in one dwelling, which had been sacked and burned, a rich treasuretrove of objects, mostly, it would appear, of domestic type, and including magnificent specimens of painted polychrome pottery. The suggestion that this was the home of a vase painter is made more than plausible by the block of red paint found in one of the rooms.

\section{Broxbourne 'Finds' at the British Museum}

A sErres of small temporary exhibitions of special prehistoric material is contemplated by the British Museum, to fill a table-case near the top of the main staircase. Following Mr. J. P. T. Burchell's exhibit of the flint sequence from Swanscombe and Northfleet in Kent is a small collection of flints from Broxbourne, Herts, all from a sealed deposit on the Pleistocene gravel. The discovery was made by $\mathrm{Mr}$. Hazzledine Warren, who is about to publish it in collaboration with Mr. Grahame Clark. The material is sharp and barely patinated, consisting of cores and end-scrapers, large and pygmy gravers, raw material in the form of blades, and two picks, the predecessors of the neolithic axe. The occupation site was covered by peat of the Boreal period, as determined by pollen analysis, and the industry may safely be referred to that cool and dry period. of pine and hazel forest which followed the arctic spell at the close of the Palæolithic. This Boreal period corresponds to the Ancylus stage of the Scandinavian Stone Age, and may be dated about 6000 B.c. This exhibition will continue through July and August, and will be followed by others dealing mainly with the Stone Age of Britain.

\section{Uses of Coal and its Products}

THE appearance of the first half-yearly summary of progress in research and technical development of the utilisation of coal and its by-products, issued by the Utilisation of Coal Committee of the Institute of Mining Engineers, directs attention to the change which adversity has produced in the coal industry. Until recently, it was substantially true to say that the industry was indifferent and left such matters to the consumer. The consumer has, however, reduced his consumption of coal either by greater efficiency, or by the use of substitutes, until the point has been reached when it is seen that coal consumption must be cultivated if coal production is to exist. The Institution is now issuing frequent bulletins which direct attention to new developments and ideas respecting the use of coal and its products. They are interesting and informative documents and reveal a departure from the 'raw coal' mentality which has been an obsession with the coal producer. Coal will only survive in face of competition by the use of methods which are efficient and convenient, and frequently this is not the case with the use of crude lump fuel. The bulletin reports that the outstanding development during the last six months has been in the use of compressed coal-gas for driving public service vehicles. For these engines, coal-gas is an almost ideal fuel, and the disadvantages of com. pressed gas are least felt when the vehicles ply within a limited radius.

\section{Grasshopper Plague in the United States}

According to a Wire Report of Science Service, Washington, D.C., dated June 9, grasshoppers are likely to be a more serious plague in the north- 
western United States, to so far south as Arizona, than at any time in the past fifteen years. A survey just completed by field men of the United States Bureau of Entomology shows that the eggs have survived the winter to a remarkably complete degree and now, with the sudden onset of hot weather, hatching is taking place with rapidity. The grasshoppers can be controlled by the proper distribution of bran baits poisoned with arsenic - a method that is usually adopted by farmers with monetary aids from the respective States or counties. With the fiscal affairs of the States none too good and some of them desperate, supplies of the necessary ingredients may be lacking in localities where infestation is greatest especially in South Dakota. Minnesota, on the other hand, with a lighter attack, has still funds in hand for financing a properly organised campaign.

\section{Genetical Society's Fund for Displaced Scientific Workers}

THE Genetical Society is raising a fund for the benefit of genetical workers, regardless of nationality, who have lost their positions as a result of racial or political discrimination, to be administered by the Society's committee, in co-operation with relief organisations. Grants will be made to as many individuals as the sum subscribed will warrant, in order to assist them to carry on research work in the British Empire. Subscriptions should be sent to Miss E. R. Saunders, 10 Newnham Terrace, Cambridge.

\section{A New Meteorite}

The Tass Agency has recently reported from Archangel that a new moteorite has fallen in the northern area of the U.S.S.R., 15 kilometres from the River Mezeni, in the vicinity of the village of Koslail. A piece of the meteorite weighing approximately two and a half tons was discovered near the meteorite itself. The Soviet Academy of Sciences (Meteorite Department) is making arrangements to investigate the new meteorite.

\section{Announcements}

IT is announced in the Times that Prof. Gilbert Murray has been elected chairman of the International Commission on Intellectual Co-operation and $\mathrm{Mme}$. Curie and Prof. Roccohave been elected vice-chairmen.

THe following have been elected officers of the Institution of Electrical Engineers for the year 1933-34: President, Mr. P. V. Hunter; VicePresident, Mr. R. P. Sloan; Treasurer, Mr. P. Rosling.

IT is announced in Science that Prof. James Franck, who recently resigned the chair of physics in the University of Göttingen, has been appointed for the coming academic year to be Speyer guest professor at the Johns Hopkins University.

ProF. D. P. D. WILKIE, professor of surgery in the University of Edinburgh, has been appointed a member of the Medical Research Council in succession to Mr. Wilfred Trotter, who retires in rotation on September 30 next, after four years' service.

Mr. E. J. Elford, borough engineer and surveyor of Wandsworth, past president of the Institution of Municipal and County Engineers, and chairman of the Building Divisional Council, has been elected to succeed Mr. M. F. G. Wilson as ehairman of the General Council of the British Standards Institution for the ensuing year.

IN NaTrRe of July 15, p. 96 , the date of the London session of the International Congress of Anthropological and Ethnological Sciences is wrongly announced as 1933. It should be 1934, as it is arranged so as to divide the interval between the Prehistoric Congresses of 1932 and 1936, and to fall in the same year as the European session of the International Congress of Americanists, namely at Seville in 1934.

Referring to the article entitled "New Science Laboratories in Aligarh" in Nature of July 15, Messrs. Adam Hilger Ltd. inform us that they have, in the past few years, supplied to the Aligarh Muslim University quartz spectrographs, an infra-red spectrometer, a Michelson interferometer and other apparatus, and that they have now under construction for the Physical Laboratory a 2-metre vacuum grating spectrograph of high dispersion in which the grating is used at nearly grazing incidence.

THE Institution of Electrical Engineers has published an index to vols. 60-69 (1922-1931) of its Journal. This is the sixth ten-yearly index it has published since 1872. These indexes are of great value for reference.

Applications are invited for the following appointments, on or before the dates mentioned :-A chief lecturer, and a lecturer in mechanical and civil engineering at the Rotherham College of Technology and Art-The Director of Education, Education Offices, Rotherham (July 29). An assistant science and mathematics master at the Exeter Junior Technical College-The Secretary for Education, 39, Southernhay West, Exeter (July 29). A head of the Department of Electrical Engineering and Physics at the Leeds Technical College-The Director of Education, Education Offices, Calverley Street, Leeds (July 31). A demonstrator in zoology at the University of Leeds-The Registrar (Aug. 5). A reader in physics at the University of Dacea, IndiaThe Registrar, University of Dacca, P.O. Ramna, Dacca, East Bengal (Aug. 31). A university reader in pharmaceutics at the College of the Pharmaceutical Society-The Academic Registrar, University of London, S.W.7 (Sept. 14). A teacher of science and a domestic science mistress at the Chatham Day Technical School for Girls - The District Education Officer, 15, New Road Avenue, Chatham. 